\title{
Design Thinking Project Management framework
}

\section{Design Thinking Project Management framework}

\author{
Daniel de Salles Canfield, Universidade Federal de Goiás \\ danielscanfield@gmail.com
}

\author{
Maurício Moreira e Silva Bernardes, Universidade Federal do Rio Grande do Sul \\ mmbernardes@gmail.com
}

\begin{abstract}
This article aims to propose a framework that integrates Project Management (PM) components with Design Thinking (DT), for minimizing the simplicity and superficiality of DT implementation. The research adopts an exploratory descriptive approach based on design science research (DSR) and uses a qualitative method, starting data collection through an interview by email, followed by an online discussion forum, a product development workshop, interviews with experts, an online framework development workshop, and finally a framework validation workshop. The result is a framework called Design Thinking Project Management framework, which contains five components - principles, roles, phases, events and tools - of PM integrated with those of DT. The relevance of the study is associated with filling an existing gap, as a result of the small number of studies integrating these two themes. It can be used by scholars and practitioners for a more complete implementation of DT projects.
\end{abstract}

Keywords: Design Thinking, Project Management, framework, components, DTPMf.

\begin{abstract}
Resumo
O objetivo deste estudo é propor um framework de integração dos componentes do Gerenciamento de Projetos (GP) com os do Design Thinking (DT), para minimizar a simplicidade e superficialidade de implementação do DT. A pesquisa adota uma abordagem exploratória descritiva com base na design science research (DSR) e assume um método qualitativo, iniciando a coleta de dados pela entrevista por e-mail, seguida do fórum de discussão on-line, entrevista com especialistas, workshop de desenvolvimento do produto, workshop on-line de desenvolvimento do framework e finalizando no workshop de validação do framework. $O$ resultado é um framework, denominado Design Thinking Project Management framework, que contempla cinco componentes - princípios, papéis, etapas, eventos e ferramentas - do GP com os do DT. A relevância do estudo está associada ao preenchimento de uma lacuna existente da decorrência de um pequeno número de estudos integrando esses dois temas, podendo ser utilizado por estudiosos e profissionais na implementação mais completa de projetos de DT.
\end{abstract}

Palavras-chave: Design Thinking, Gerenciamento de Projetos, framework, componentes, $D T P M f$. 


\section{Introduction}

Global research has shown that, although extremely important, projects are not being developed effectively. According to Kumar (2013), only 4\% of organizational innovation projects are successful, which means that $96 \%$ of them are unsuccessful. Von Hippel (2007) explains that $70 \%$ to $80 \%$ of new product development projects are not successful because they fail to focus on one of the main requirements of design, namely user understanding. The annual survey Pulse of the Profession ${ }^{\circledR}$ by PMI (2017) translates poor project performance into figures: $\$ 97$ million is wasted for every $\$ 1$ billion invested. Consequently, the way of approaching projects must be improved, taking into account aspects that can streamline both their development and their result.

For every project or change, there is a need for management (TURNER, 2009). The concept of 'new' cannot be incompatible with the concept of 'management', since the successful outcomes of innovation are associated with the adoption of disciplined and well-developed processes and methods (KUMAR, 2013). Thus, the lack of proper management (CBD, 2016) can compromise the development of projects or even prevent them from happening (MJV, 2017). Therefore, PM is an aspect to be handled more carefully in the quest for truly effective projects.

With the basic principle of involvement and a deep understanding of real users and customers during the creation of new perspectives and solutions (D.SCHOOL, 2012), DT - originated in the field of cognition in design - is being disseminated as an approach used by interdisciplinary teams for the creative resolution of ill-defined problems (TSCHIMMEL et al., 2017). The subject has been gaining increasing interest in the academic and business worlds (LIEDTKA, 2018), since it addresses projects differently by migrating from the traditional linear process to a process with nnovation spaces (BROWN, 2008).

Although DT has proven its efficiency in numerous cases (LIEDTKA, 2018), the academic discourse has been modestly explored (GRUBER et al., 2015). A more rigorous scientific analysis of it is still in its infancy (PLATTNER; MEINEL; LEIFER, 2012); therefore, more critical thinking on the topic is needed (KIMBELL, 2011) to minimize the lack of theoretical foundation required for a more comprehensive assessment and for its own evolution (AUERNHAMMER; ROTH, 2021). One of the main possible causes of this situation is the novelty of the theme. Introduced in 2003 in the United States of America (BROWN; WYATT, 2010; NITZSCHE, 2012) and, in 2010, in Brazil (CIEB, 2016; NITZSCHE, 2012), DT still needs to be further studied and developed to become academically mature as a theme.

Another cause may be the strong criticism of DT from the academic and managerial community: it is seen as simplistic and superficial. According to Dorst (2015), DT can be considered to be an opportunistic practice, as it deals only superficially with some techniques. Almendra and Christiaans (2013) noted that the image of DT has been unnecessarily hurt because consulting firms have offered it in simplistic and abusive way, as a management tool or a simple innovation recipe.

Liedtka and Ogilvie (2011) stated that although DT is a way of visualizing problems in a different way, it does not replace analytical thinking; therefore, according to Vianna et al. (2012), its combination with other development practices produces more assertive solutions. To approach DT in a less superficial and more comprehensive way, it is presumed that there needs to be a 
change of perspective, whereby DT will be understood as a single and temporary project. Just as any project needs management (TURNER, 2009), the effective and efficient development of DT is also associated with the adoption of disciplined and well-developed processes and methods. A DT project is not just based on execution components, but also on initiating, planning, monitoring and controlling, closing components. It needs to be structured and holistic, and it requires systematic management with a beginning, middle and end.

PM takes on a permanent and formal function to ensure the highest probability of success for a DT project. The inclusion of management aspects, such as integration, scope, schedule, cost, quality, resource, communication, risk, procurement and stakeholder, will result in a reduction in the superficiality of DT and an increase in trust and credibility in it, as it will have new phases and management tools throughout the process.

During the artifact identification phase, there were only 10 frameworks that use a combination of DT and PM. However, there was a clear lack of a framework that uses the theoretical and practical components of DT with those of PM, both traditional and agile. For instance, the frameworks proposed by Omeje (2015) and Amorim (2017) use only the practical components of PMBOK ${ }^{\circledR}$, showing the lack of practical components of agile GP. On the other hand, the framework by MJV (2018a) is entirely built on the practical components of SCRUM, excluding any reference to traditional PM. Other frameworks focus excessively on specific components, such as time (LEE, 2007; TEIXEIRA et al., 2017) and the individual (O'TOOLE, 2015), which reduces the possibility of generalizing the framework.

Overall, although DT has the potential to positively contribute to the creation of organizational solutions in different areas, it still has some limitations. Using an exploratory descriptive research, specific phases of design science research and six qualitative data collection instruments, this article attempts to integrate the components of DT with PM through a framework - a support structure (MOSELEY et al., 2005) presenting recommendations of concepts, principles and phases created on the basis of theories and design practices (ROGERS; SHARP; PREECE, 2013) - to answer the following question: How can Design Thinking benefit from Project Management components?

\section{Literature Review}

This section presents the theoretical basis of Design Thinking and Project Management used to support this study.

\subsection{Design Thinking}

DT is a "fascinating world - deep and wide" (LOCKWOOD, 2009, p. 20). A concept or practice that has been applied long before the term was coined (KIMBELL, 2011; NITZSCHE, 2012) consciously or unconsciously (COOPER; JUNGINGER; LOCKWOOD, 2009), before design was regarded as a profession, or even millennia ago by thinkers of all disciplines (DMI, 2013).

Nonetheless, Table 1 shows two relatively stable discourses as far as DT is concerned (ALMENDRA; CHRISTIAANS, 2013). The first, written in lowercase letters (design thinking) 
appeared two decades before the second, and it is focused on researching the mental process of designers during projects (TSCHIMMEL, 2012); in other words, how they actually handle their own work and assign meaning to it (KIMBELL, 2011). The second, written with capital initials (Design Thinking) is much more recent and is focused on business innovation through a thinking process rooted in design culture (TSCHIMMEL, 2012). It is a simplified version of the first, in which design methods are applied in the organizational field by different professionals in several contexts, thus breaking the design barrier (JOHANSSON-SKOLDBERG; WOODILLA; ÇETINKAYA, 2013).

Table 1 DT discourses and concepts. Source: Authors (2021).

\begin{tabular}{|c|c|c|c|}
\hline Concept & Precursors & Reference & Focus \\
\hline \multicolumn{4}{|c|}{ design thinking discourse } \\
\hline $\begin{array}{l}\text { DT as a cognitive } \\
\text { style }\end{array}$ & $\begin{array}{l}\text { Creation of artifacts (Simon, 1969), wicked } \\
\text { problems (Rittel, 1972), way of reasoning } \\
\text { (Jones, 1962; Gregory, 1966; Lawson, 1980; } \\
\text { Rowe, 1987; Schön, 1983) and thinking visually } \\
\text { (Mckim, 1972) }\end{array}$ & $\begin{array}{l}\text { Cross }(1982) \\
\text { in the USA }\end{array}$ & $\begin{array}{l}\text { Solving (design) problems } \\
\text { through the designers' individual } \\
\text { mental process }\end{array}$ \\
\hline $\begin{array}{l}\text { DT as a general } \\
\text { theory of design }\end{array}$ & $\begin{array}{l}\text { Everyday experience (Dewey, 1934) and wicked } \\
\text { problems (Rittel, 1972) }\end{array}$ & $\begin{array}{l}\text { Buchanan } \\
\text { (1992) in the } \\
\text { USA }\end{array}$ & $\begin{array}{l}\text { Control wicked problems (from } \\
\text { different areas) through an } \\
\text { integrated process of knowledge } \\
\text { of art and science }\end{array}$ \\
\hline \multicolumn{4}{|c|}{ Design Thinking discourse } \\
\hline $\begin{array}{l}\text { DT as an } \\
\text { organizational } \\
\text { resource }\end{array}$ & $\begin{array}{l}\text { design thinking discourse and DeepDive } \\
\text { Methodology (IDEO, 2001) }\end{array}$ & $\begin{array}{l}\text { IDEO }(2003) \\
\text { in the USA }\end{array}$ & $\begin{array}{l}\text { Generating organizational } \\
\text { innovation through a process, } \\
\text { based on design, with defined } \\
\text { phases and tools. }\end{array}$ \\
\hline
\end{tabular}

This DT concept, which has become deeply popular in recent years, endows organizations with a broader perspective of design, going beyond mere aesthetics and empowering the transformation of the innovation process, promoting corporate culture and generating sustainable competitive advantage (BEST, 2011; BROWN; WYATT, 2010; MARTIN, 2010). Brown (2008) believes that DT can strongly collaborate with business, since its best practices are vastly disseminated and encouraged to be copied and explored.

There are an increasing number and variety of publications, cards, books, methods and techniques centered on this approach (VAN DER BIJL-BROUWER; DORST, 2017), which is adopted by different organizations, in different contexts, such as start-ups, small businesses, large companies, non-profit companies, government and the social sector (BROWN, 2009; BROWN; WYATT, 2010; DORST, 2015; INNS, 2013; KELLEY; KELLEY, 2013; LIEDTKA, 2014, 2018; MJV, 2018b; SOBEL; GROEGER, 2013).

\subsection{Project Management}

Project Management is a dynamic and developing subject (TURNER, 2009). Over the years, organizations have intensified their focus on short- and long-term benefits and implementation of change through a dynamic PM, properly aligned with their strategy (IPMA, 2015) and applied to different sectors, such as construction, products, advertising, hospitals, government (KERZNER, 2015). 
As in DT, the conceptualization of PM comes with duality (Table 2): two aspects fight over space; however, they are similar as to the goal of excellence in project execution (VARGAS, 2016), the team's disciplinary process (PRIES; QUIGLEY, 2011), the type of work, such as the creation of requirements, development, documentation and product integration (LAYTON; OSTERMILLER, 2017).

Table 2 PM concepts. Source: Authors (2021).

\begin{tabular}{llll}
\hline Concept & Precursors & Reference & Focus \\
\hline Traditional & Taylor (1911) and Gantt & U.S. Department of Defense contractors and Sequential process with \\
PM & $(1917)$ & construction companies (1960s) & defined challenges \\
Agile PM & Traditional PM and Takeuchi & Agile manifesto (2001) & Iterative process with \\
& and Nonaka (1986) & & undefined challenges \\
\hline
\end{tabular}

The first aspect, regarded as the old method (SUTHERLAND, 2014), is the traditional PM, which follows a waterfall approach, in which each step occurs sequentially (AXELOS, 2017). One step needs to be completed so that the next one to can be started (STERN, 2017) and the requirements have to be defined to initiate the construction and delivery of the product (AXELOS, 2017). Project scope remains the same, but time and cost are different (NOTE, 2016). The second, considered as the new method (SUTHERLAND, 2014), is agile PM, a flexible process in which decisions are continuous, centered on the actual project (AXELOS, 2017). The process does not depend on the total completion of the steps, but on splitting into small iterations (LAYTON; OSTERMILLER, 2017). Therefore, while the project scope is variable, the deadline and costs remain the same (NOTE, 2016).

There are substantial differences between the two concepts, but it is not advisable to regard one as the best. The choice of application takes into consideration not only the popularity of a certain concept (AJAM, 2018), but also the best adequacy to the project, and the most favorable approach to the solution (NOTE, 2016). If possible, integration (COOPER; SOMMER, 2016) and combination of both of them should also be considered to provide PM supported on the steady basis of traditional PM, albeit with the flexibility and continuous communication of agile PM (STERN, 2017).

\section{Methods}

Based on the objectives of the present study, a descriptive exploratory approach was adopted, since it can be an extension of exploratory research that helps to clarify phenomena and data collection (SAUNDERS; LEWIS; THORNHILL, 2016). However, owing to the creative and abductive approach - common characteristics of design science research (DSR $\left.{ }^{1}\right)(\mathrm{DRESCH}$; LACERDA; ANTUNES JR., 2015) and DT, - two phases belonging to DSR were introduced to this research (Figure 1): (i) development - creation of an $\operatorname{artifact}^{2}$ for solving a problem; (ii) validation - testing of the artifact, through the comparison between the framework's performance and the previously defined requirements.

${ }^{1}$ Approach that advocates practical relevance in all scientific research. 2 Symbolic representation or a physical instance of design concepts.

Estudos em Design | Revista (online). Rio de Janeiro: v. 29 | n. 3 [2021], p. 66 - 86 | ISSN 1983-196X 


\section{COMPREHENSION (Literature review)}

PLANNING Identification and awareness of the problem and identification of the artifact

\section{EXECUTION Data collection}

ANALYSIS Data processing, analysis and interpretation

Framework design and development DEVELOPMENT

$$
\text { Framework evaluation VALIDATION }
$$

\section{Writing the report, explaining the lessons learned, conclusions and generalization $\quad$ CLOSING}

Figure 1 Research phases. Source: Authors (2021).

Regarding the research strategy - analyzed from the point of view of the problem approach the study assumed a qualitative method, predominating the character of deep understanding of the theme (LEAVY, 2017). Six data collection instruments (Table 3) were applied - interview by email, online discussion forum, product development workshop, interview with experts, online framework development workshop and framework validation workshop - and the data were analyzed through content analysis using the MAXQDA software.

Table 3 Data Collection Instruments. Source: Authors (2021).

\begin{tabular}{lll}
\hline Date & Instrument & Sample \\
\hline Sep/2017 & Interview by email & 5 designers specialized in DT \\
Aug/2018 & Online discussion forum & 36 participants from the DT group (LinkedIn) \\
Dec/2018 - Dec/2019 & Product development workshop & 8 participants from Company X and 3 from ID \\
Mar - Aug/2019 & Interview with experts & 10 experts in DT and PM \\
Apr - Jun/2020 & Online framework development & 9 ID members and 3 ID partners \\
& workshop & \\
Jul - Aug/2020 & Framework validation workshop & $\begin{array}{l}\text { 5 participants from Company Y, 1 client of the } \\
\text { company and the researcher }\end{array}$ \\
\hline
\end{tabular}

\subsection{Interview by email}

The interview aimed to collect specific information about DT to find out what the researched subjects "think, know, represent and argue" (SEVERINO, 2013, p. 77). Thus, a structured interview was conducted by email, since this technological tool allows researchers to interact with respondents through a series of emails (SAUNDERS; LEWIS; THORNHILL, 2016) to address subjects in a vast geographical space, to extract answers with a high level of objectivity and keep them within the limits of the questions (OLIVEIRA; VIANNA, 2018).

It was sent in September 2017 to five designers (Table 4) who research and apply DT in their professional careers. Their responses helped to identify positive and negative points about DT, which supported the definition of the research problem and objectives. 
Table 4 Profile of the respondents to the interview by email. Source: Authors (2021).

\begin{tabular}{llll}
\hline Participant & Background & Job title & Experience \\
\hline P1I1 & Engineering & Professor and owner of d-think & 42 years \\
P2I1 & Design & Professor and owner of Ideia Café & 13 years \\
P3I1 & Graphic design & Innovation and Design Manager at Icatu Seguros & 22 years \\
P4I1 & Graphic design & Design Lead at Brim Financial & 14 years \\
P5I1 & Materials Engineering & Director at the Office of Innovation, Science and & 8 years \\
& & Technology of RS & \\
\hline
\end{tabular}

\subsection{Online discussion forum}

An asynchronous forum was created to collect the opinion of people knowledgeable about DT, regarding the difficulties of implementing the approach. This instrument was used to gather data over the Internet (STEWART; SHAMDASANI, 2016) in an observable, accessible, secure and collaborative manner (REDLICH-AMIRAV; HIGGINBOTTOM, 2014).

Also known as web forum, forum, discussion group, and bulletin board (SAUNDERS; LEWIS; THORNHILL, 2016), the online discussion forum used the Design Thinking group ${ }^{3}$ on the social network LinkedIn to engage 36 participants in a discussion (identified by the code PnF) by starting surveys, answering new questions, and interacting with the responses of other respondents.

\subsection{Product development workshop}

To generate practical information, test insights, and contextualize elements to build the framework, a product development workshop was conducted. The focus was placed on creating a product according to the context and need of the company chosen for the study, referred to as Company X in this study. Founded in 1993, it is an organization that designs, manufactures and markets materials for craniofacial surgeries. It is a small company with 25 employees, which turned to the Institute of Design ${ }^{4}$ (ID) for help in implementing DT and PM in its project development routine, aiming to innovate in its processes and products.

The workshop had 10 members (Table 5), who had to meet two criteria: (i) be attended by at least one leader/ person in charge from each sector of the company; (ii) be attended by the company's board of directors. The workshop was planned to have three phases: initiation, execution, and conclusion. Eighteen meetings were held, with an average duration of three hours each, over 12 months (December 2018 to December 2019).

\footnotetext{
${ }^{3}$ Largest DT group on LinkedIn, with 117,540 members.

${ }^{4}$ Fictitious name of the Institute, of which the researcher is a member, which aims to develop and disseminate research in the area of Design, Innovation, and Technology.
} 
Table 5 Profile of the product development workshop participants. Source: Authors (2021).

\begin{tabular}{llll}
\hline Participant & Background & Role & Team \\
\hline Researcher & Design & Moderator (operationalized the workshop) & ID \\
P1W1 & Civil Engineering & Coordinator (guided strategic decisions) & ID \\
P2W1 & Design & Auxiliary (facilitated the progress of activities) & ID \\
P3W1 & Mechanical Engineering & Owner & Company \\
P4W1 & Mechanical Engineering & Project manager & Company \\
P5W1 & Mechanical Engineering & Projects & Company \\
P6W1 & Mechanical Engineering & Projects & Company \\
P7W1 & Literature & Sales & Company \\
P8W1 & Mechanics & Quality & Company \\
P9W1 & Production Engineering & Production & Company \\
P10W1 & - & Administration & Company \\
\hline
\end{tabular}

\subsection{Interview with experts}

To deepen the understanding about what DT and PM are, by means of collecting information, 10 individuals (Table 6) were previously selected and invited, by phone and email, to participate in an individual interview. For this procedure, these selection criteria were used: (i) the interviewees had to be academics and/or active participants in the labor market, to obtain a theoretical and practical vision of DT and PM; (ii) the professors had to hold at least a doctoral degree and to have a published article in the specific field (DT or PM); (iii) the professionals had to have at least five years of work experience in the specific field.

Table 6 Profile of experts. Source: Authors (2021).

\begin{tabular}{lllll}
\hline Participant & Country & Expertise area & Job title & Experience \\
\hline P1I2 & Brazil & DT & Professor and head of innovation at Kepler Weber & 17 years \\
P2I2 & Brazil & DT & Global head of digital transformation at MJV & 14 years \\
P3I2 & Brazil & DT & Designer at Live | work & 9 years \\
P4I2 & Portugal & DT & Consultant at Mindshake & 9 years \\
P5I2 & Brazil & DT and PM & Professor and owner of FWK & 13 years \\
P6I2 & Brazil & DT and PM & Professor and senior specialist leader at CI\&T & 11 years \\
P7I2 & USA & DT and PM & Professor and senior program manager at UPMC & 26 years \\
& & & Enterprises & \\
P8I2 & Brazil & PM (traditional) & Owner of RF Consultancy and member of PMI-RS & 16 years \\
P9I2 & Brazil & PM (agile) & Project Manager at IBM & 17 years \\
P10I2 & Brazil & PM (agile) & Professor and owner of Surya & 19 years \\
\hline
\end{tabular}

Interviews took place between March and August 2019, and they were preferably conducted face to face, in a single meeting lasting 60-90 minutes, as indicated by Tschimmel et al. (2017). When the interview could not be conducted in person, Skype software was used as a comparable alternative to the face-to-face interview, overcoming financial and geographical boundaries (JANGHORBAN; ROUDSARI; TAGHIPOUR, 2014).

\subsection{Online framework development workshop}

To take advantage of the collaborative characteristics of the study, a workshop was held for some ID members and partners. Participants were chosen by self-selection, through an email 
invitation extended via the ID director to the 24 participants to form a diverse group of people (Table 7).

Table 7 Profile of the participants in the online framework development workshop. Source: Authors (2021).

\begin{tabular}{llll}
\hline Participant & Titration & Role & Expertise area \\
\hline Researcher & PhD student & Moderator & DT and PM \\
P1W2 & Professor & Participant (ID) & DT and PM \\
P2W2 & Doctor & Participant (ID) & PM \\
P3W2 & PhD student & Participant (ID) & DT and PM \\
P4W2 & Master's student & Participant (ID) & DT and PM \\
P5W2 & Master's student & Participant (ID) & PM \\
P6W2 & PhD student & Participant (ID) & DT \\
P7W2 & PhD student & Participant (ID) & DT and PM \\
P8W2 & PhD student & Participant (ID) & PM \\
P9W2 & Warren Brasil & Participant (external) & DT and PM \\
P10W2 & PMI & Participant (external) & PM \\
P11W2 & Pincéis Atlas & Participant (external) & DT and PM
\end{tabular}

The first session of the workshop took place on April 30, 2020, with the participation of eight people exclusively from ID. Lasting approximately two hours and 30 minutes, the main focus of the session was the construction of the above-mentioned artifact. The second workshop session took place on June 25, 2020; it brought together, again, the participants of the first online workshop and some partner experts of ID to discuss the version created by the researcher and to finalize the framework for the validation step.

Both sessions were held on Google Meet and recorded on the platform, in the researcher's notebook, and in the notes contained in the slides presentation - shared and completed by all workshop participants.

\subsection{Framework validation workshop}

To validate the selected components and the structure of the proposed framework, a specific workshop was held. The focus was placed on the development of a sales process for a company chosen for the study, referred here as Company Y. It is an organization, founded in 2017, which provides Human Resources improvement services to small, medium and large companies.

The workshop was attended by the researcher, five members of Company $\mathrm{Y}$ and a client of the Company Y (Table 8), following the same criteria of the product development workshop: (i) having at least one leader/ person in charge from each sector of the company; (ii) being attended by the company's board of directors. 
Table 8 Profile of the participants of the online framework development workshop. Source: Authors (2021).

\begin{tabular}{llll}
\hline Participant & Background & Job title & Role \\
\hline Researcher & Design & - & DT and PM master \\
P1W3 & Administration & Owner/Sales & Product owner \\
P2W3 & HR Management & Owner/ Administration & Development team \\
P3W3 & Marketing & Sales & Development team \\
P4W3 & Marketing & Implementation & Development team \\
P5W3 & Administration & Sales & Development team \\
P6W3 & Administration & - & Product User \\
\hline
\end{tabular}

During a month and a half - July to August 2020 - 12 meetings were held, with an average duration of one hour and 30 minutes each. The meetings followed the chronological order defined in the framework, starting with the initiation phase and closing with the conclusion phase. Consequently, all the events were concluded, but some tools, from DT and PM, were not used, because they would not add positive results to the project as a whole.

\section{Results}

This section presents the results according to the three steps and the degree of importance resulting from the triangulation of data collection instruments (Table 9).

Table 9 Relationship between results and data collection instruments. Source: Authors (2021).

\begin{tabular}{ll}
\hline Result & Data collection instruments \\
\hline $\begin{array}{l}\text { 4.1 Identification of the components of } \\
\text { DT and PM }\end{array}$ & $\begin{array}{l}\text { Literature review; interview by email; online discussion forum; product } \\
\text { development workshop; interview with experts }\end{array}$ \\
$\begin{array}{l}\text { 4.2 Analysis of the components of DT } \\
\text { with those of PM }\end{array}$ & Online framework development workshop \\
$\begin{array}{l}\text { 4.3 Validation of the components and } \\
\text { structure of the proposed framework }\end{array}$ & Framework validation workshop \\
\hline
\end{tabular}

\subsection{Identification of the components of DT and PM}

Briefly, components were identified to belong to two categories: (i) theoretical components of DT - integration, optimism, empathy, collaboration, visualization, and iteration - and of PM transformation, integration, optimism, resolution, collaboration, communication, and visualization (Table 10); (ii) practical components of DT - models, phases, and tools - and of PM - models, roles, phases, events, and tools and processes. 
Table 10 Identified Theoretical Components of DT and PM. Source: Authors (2021).

\begin{tabular}{|c|c|c|c|}
\hline Categ. & Component & Concept & Example \\
\hline DT & Integration & $\begin{array}{l}\text { Combining analytical and } \\
\text { intuitive thinking }\end{array}$ & $\begin{array}{l}\text { This requires an analytical - considered as "spreadsheet } \\
\text { thinking" (P1I2) - and creative approach. }\end{array}$ \\
\hline DT & Optimism & $\begin{array}{l}\text { Trusting the approach and } \\
\text { yourself }\end{array}$ & $\begin{array}{l}\text { It is necessary to "create a trust-based approach. If that } \\
\text { doesn't exist, it won't work" (P22F). }\end{array}$ \\
\hline DT & Empathy & $\begin{array}{l}\text { Understanding the user's } \\
\text { needs and desires }\end{array}$ & $\begin{array}{l}\text { "If we can't understand what the needs are, the project ends } \\
\text { up being more superficial" (P4I1). }\end{array}$ \\
\hline DT & Collaboration & $\begin{array}{l}\text { Co-creating through } \\
\text { multidisciplinary teams }\end{array}$ & $\begin{array}{l}\text { "It is much better to collaborate than to compete, everyone } \\
\text { benefits from that" (P6I2). }\end{array}$ \\
\hline DT & Visualization & Using visual tools & $\begin{array}{l}\text { "Writing, drawing, painting, we adhered to that and it made } \\
\text { communication clear and objective for everyone" (P10W1). }\end{array}$ \\
\hline DT & Iteration & $\begin{array}{l}\text { Repeating steps until the } \\
\text { process is finished }\end{array}$ & $\begin{array}{l}\text { "Experimentation is a quick way for us to test and see if it } \\
\text { fits the values and if that is the way the company will go" } \\
\text { (P3I2). }\end{array}$ \\
\hline $\mathrm{PM}$ & Transformation & $\begin{array}{l}\text { Switching from the current to } \\
\text { the desired state }\end{array}$ & "It's a continuous flow of continuous learning" (P10I2). \\
\hline $\mathrm{PM}$ & Integration & $\begin{array}{l}\text { Combining different } \\
\text { knowledge and skills }\end{array}$ & $\begin{array}{l}\text { "Being someone who's a dreamer, realistic and critical" } \\
\text { (P1I1). }\end{array}$ \\
\hline PM & Optimism & $\begin{array}{l}\text { Building trust among the } \\
\text { participants }\end{array}$ & $\begin{array}{l}\text { "Because if they had confidence, I would know that } \\
\text { everything is okay" (P10I2). }\end{array}$ \\
\hline PM & Resolution & Focusing on the desired result & "Well-defined goals, correctly laid out” (P9I2). \\
\hline PM & Collaboration & $\begin{array}{l}\text { Executing projects through } \\
\text { multidisciplinary teams }\end{array}$ & Bringing together "people of $\mathrm{x}, \mathrm{y}$ and $\mathrm{z}$ expertise" (P6I2). \\
\hline PM & Communication & Keeping people informed & $\begin{array}{l}\text { "Communicating is about keeping people on the same page" } \\
\text { (P7I2). }\end{array}$ \\
\hline PM & Visualization & Using visual tools & "Having a simpler, more illustrative approach" (P8I2). \\
\hline
\end{tabular}

\subsection{Analysis of the components of DT with those of PM}

After identifying the components of DT and PM separately, a joint analysis was executed to recognize whether or not they were compatible and complementary. By interpreting the perceptions of the participants of the workshop, it was possible to analyze the components, suggest new ones, and integrate the elements of DT and PM.

The components were analyzed according to two classifications. First, the principles nomenclature adopted for the theoretical components - of DT and PM were analyzed (Figure 2), and a high degree of compatibility was found to occur, since four of them have the same denomination and purpose in both themes. There was also strong complementarity between them, since DT principles - iteration and empathy - can complement PM, and PM principles resolution, communication, and transformation - can complement DT. 


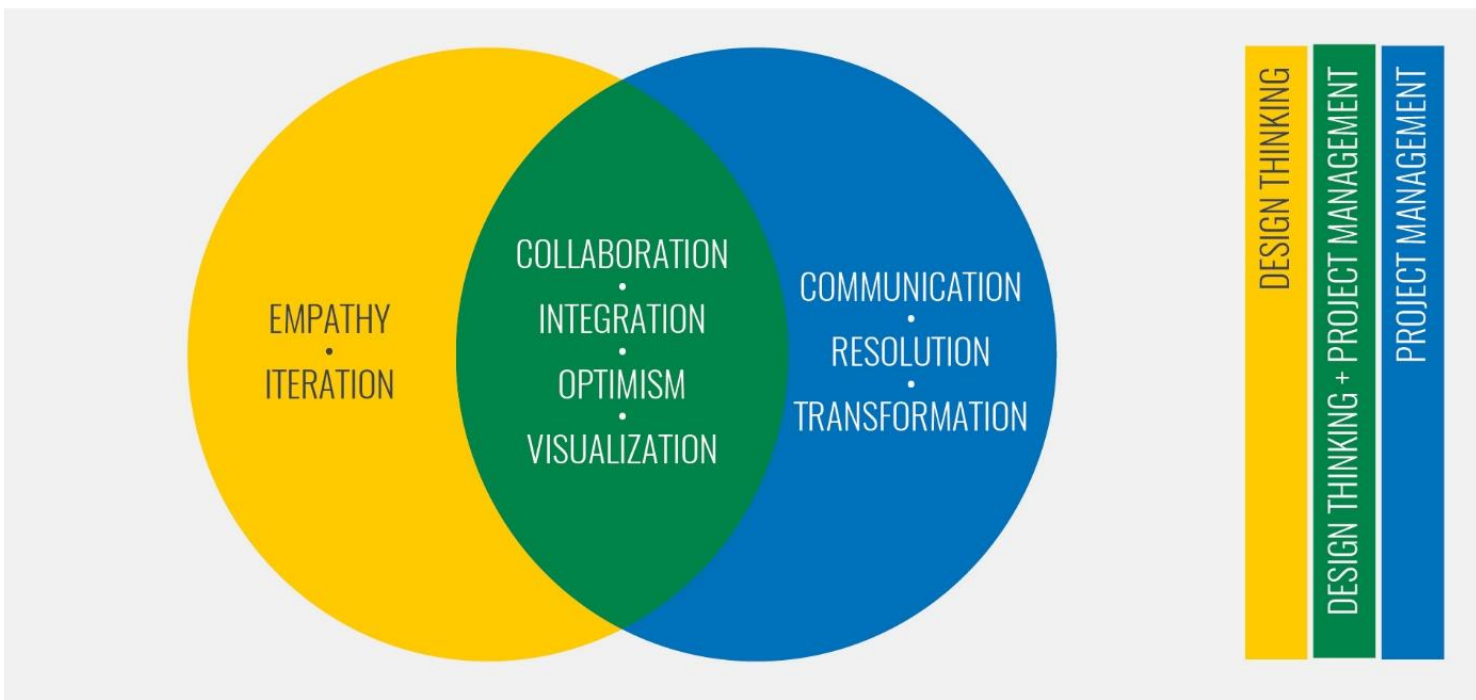

Figure 2 Relationship between the principles of DT and PM. Source: Authors (2021).

Finally, the practical components identified earlier - roles, phases, events, tools -, were analyzed and related. Owing to the comment "it seems quite separate. So is PM, DT and a team. Who is the team?" (P5W2), there was a need to add new roles and to combine some of them, which resulted in a project team (Figure 3) composed of the product owner, PM master - a person who has understanding and ability to propagate traditional and agile PM -, DT master -knowledge and ability to transmit DT theory and practice -, development team and product user.

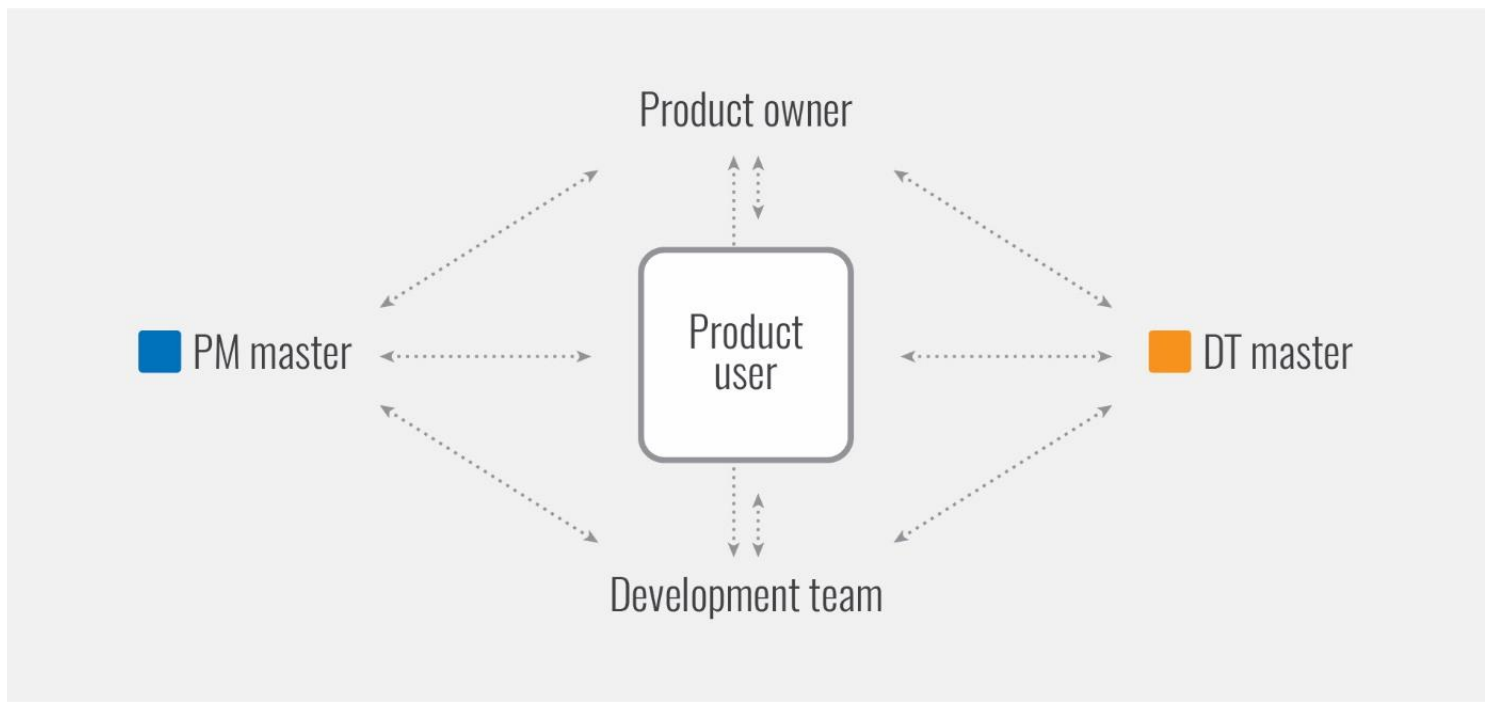

Figure 3 Framework project team. Source: Authors (2021).

Considering that a DT project should not be limited to the DT phases, the three phases of PM (Figure 4) provide the basic support for managing the project and should be carried out sequentially, from left to right. The three phases of DT must be performed sequentially or iteratively, as it is a process of iterative cycles of exploring user needs, generating ideas and testing the best ideas. Each phase of DT must have two sequential moments: a divergent one - analysis - and a convergent one - synthesis. 
Although the immersion phase was preliminarily defined to start after the end of the initiation phase, it was extended to "the middle of the initiation, so that I have a project start, more details, stronger planning, achieving both parts [initiation and planning]. It is especially useful in the project charter" (P11W2).

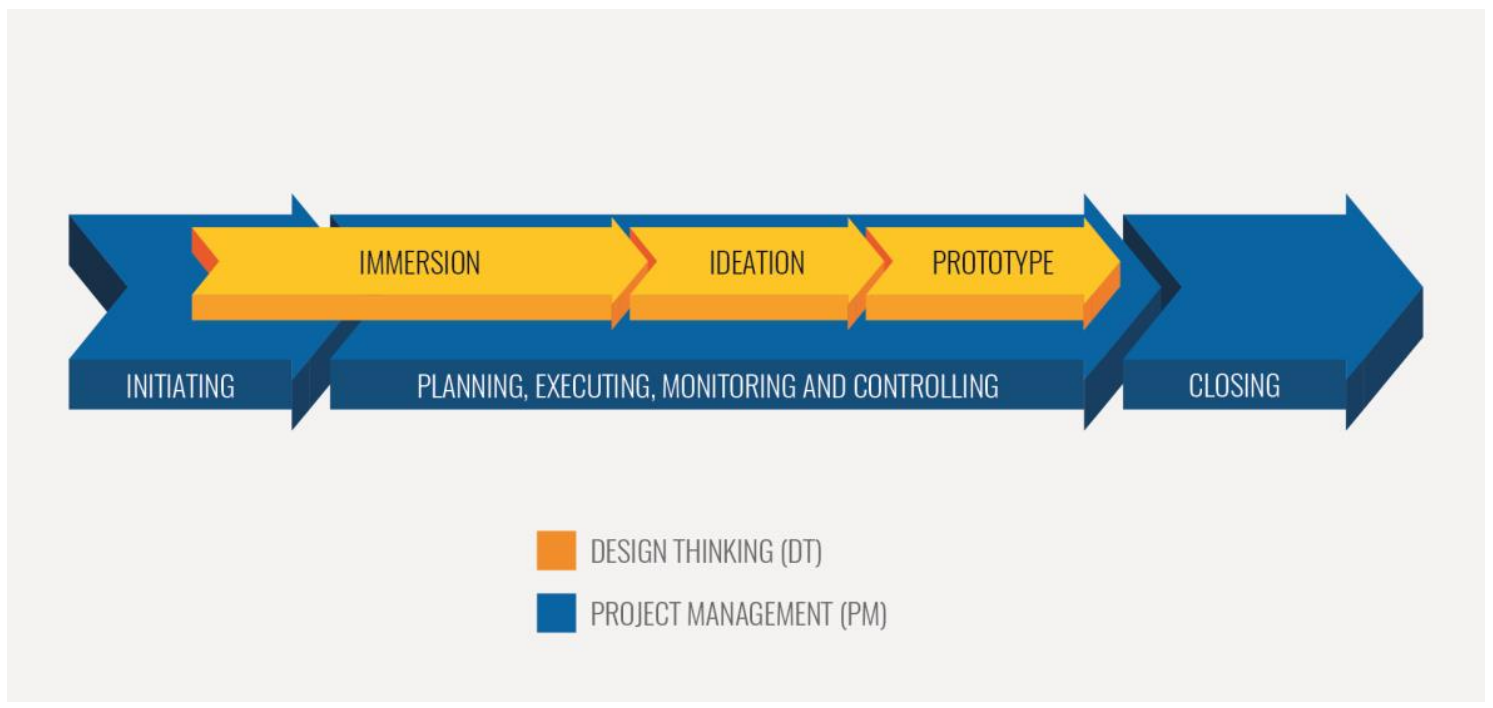

Figure 4 Framework phases. Source: Authors (2021).

Recommended to be executed fully and when they appear in the framework to avoid the lack or the excess of activities, the events were divided into three moments: planning, Sprint and review. However, the events identified previously - Sprint planning, daily meeting, Sprint review, and phase review - were adapted and added to others for greater integration between DT and PM. For instance, Sprint - originating from Scrum - is associated with the completion time of a DT tool, and Sprint planning, daily meeting and Sprint review were also related to the same tool (Figure 5). The Sprint retrospective was removed from the framework and added to the phase review to eliminate possible duplication, as the phase review has the retrospective questions, "I would have feedback from the participants, the team, a self-assessment and that would give me subsidies to assess whether it goes to the next phase or returns" (P7W2). 


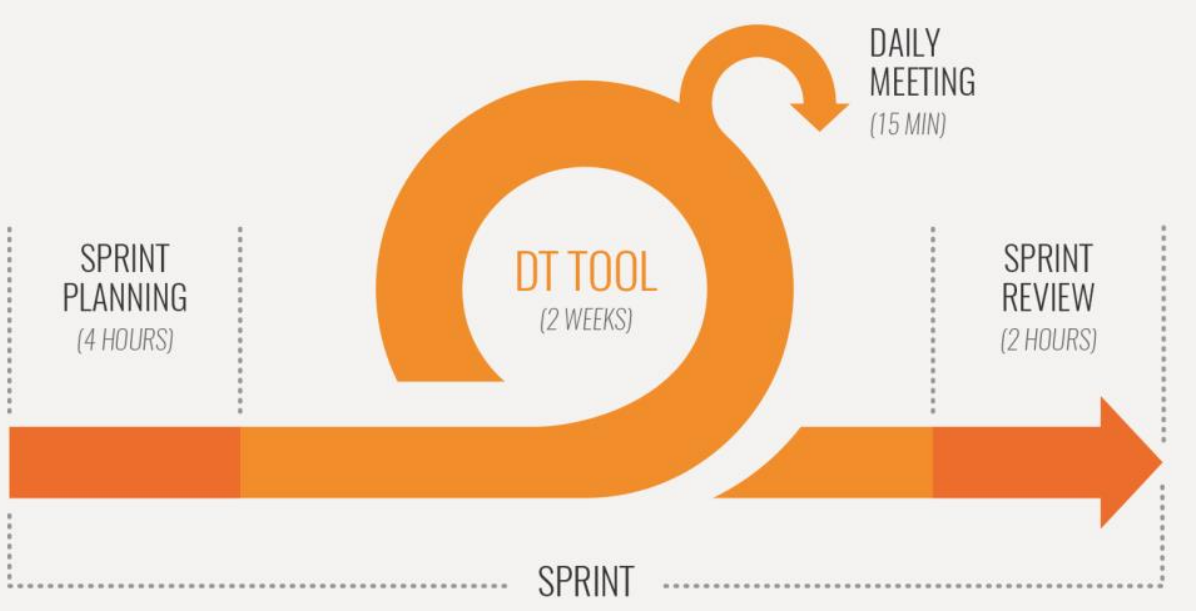

Figure 5 Framework Sprint. Source: Authors (2021).

Considering the flexibility required by the framework, the DT and PM tools are not arbitrarily imposed, but rather presented and suggested. For "the moment I say that it is necessary to use this tool, that tool, and the other tool, I eliminate half of what DT gives me. But I think it would be okay if we list exemplary suggestions" (P6W2). Thus, each tool of the framework can be used in full, adapted, replaced or even not used, depending on the need of the project.

\subsection{Validation of the components and structure of the proposed framework}

To evaluate the visual structure of integration of the components of DT and PM, a workshop for validation of the framework was conducted to test the effectiveness of the framework in practice, because "we never follow an approach by the book, we always make adaptations [...] and each project we touch has a particularity" (P9W2).

These are some of the main results that can be highlighted: (i) the project team can embrace the principles and practice them during the project development; as stated by P1W3, "people realize that there is a role, that we are not locked in a little box, where we only do a couple of things. The team clearly understood the impact of each person's work"; (ii) the phases of the PM are more difficult to interpret, as emphasized by P5W3: "it is a bit arduous at the beginning. As we progress, the logic is understood. Today, when I see this here - starting with the initiation, doing the planning, doing the review, advancing to the next step -, everything becomes clear"; (iii) the events fulfilled the objective of creating a routine of meetings that was necessary for the progression of the phases. For example, the planning phase was essential for the project team to understand what needed to be done, because it was the moment to ask questions - "so, do we have any activities for the next meeting?" (P4W3).

\section{Design Thinking Project Management framework}

This section presents the final artifact of the investigation. Owing to the need for a selfexplanatory visual structure, the Design Thinking Project Management framework (DTPMf) was divided into two versions - short and complete. 


\subsection{DTPMf(short version)}

The short version of the DTPMf (Figure 6) is intended to present an overview of the five components of the artifact and their interactions. Thus, this version cannot be used separately from the complete version, i.e., a DT project cannot be done based only on the short version. It does not present the components in detail, but it is only a framework for introducing DTPMf.

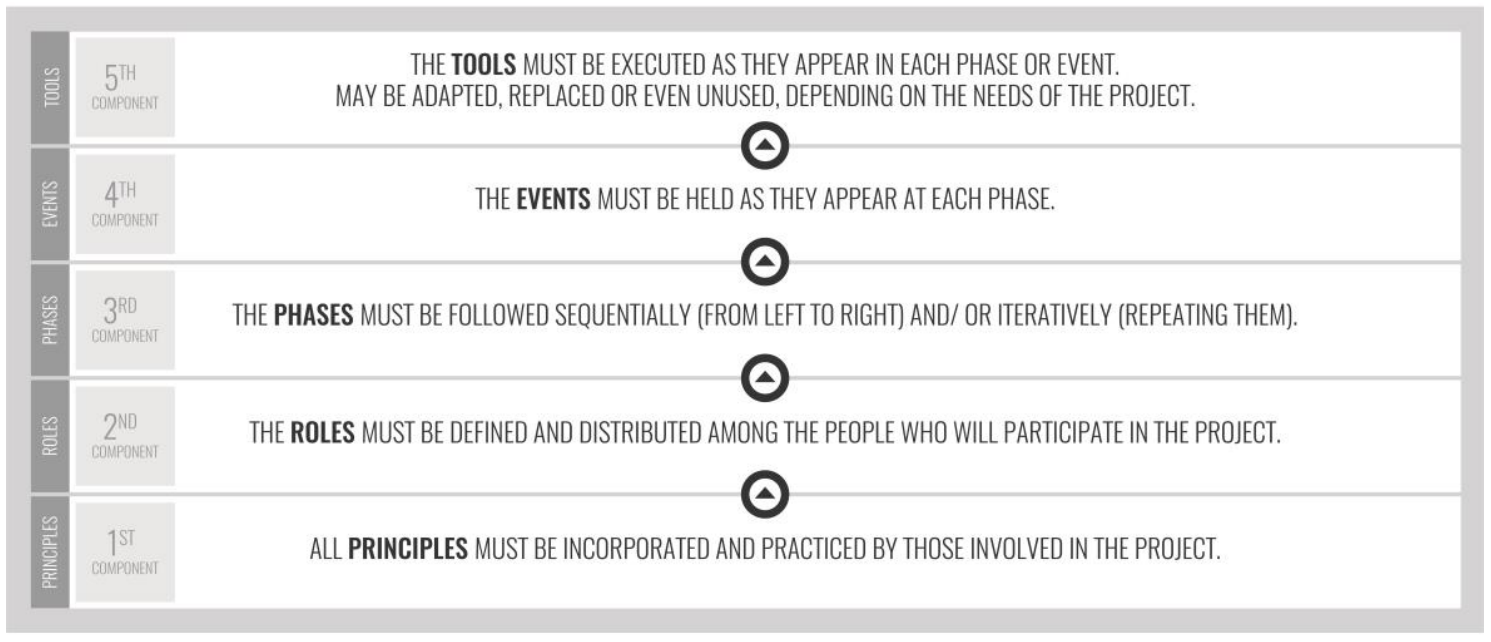

DESIGN THINKING PROJECT MANAGEMENT FramewORK | SHORT VERSION

Figure 6 DTPMf short version. Source: Authors (2021).

This version contains identical aspects to the complete version of the DTPMf, with the same rectangular format and the same horizontal divisions where the five components are distributed. However, some distinctions were made, for example: the components were summarized in short action phrases, containing what must be done in each one; a numerical and symbolic sequence was introduced, showing that the components must be understood and executed from bottom to top - starting with the principles, going through roles, phases and events, and finally arriving at the tools.

\subsection{DTPMf (complete version)}

The DTPMf, shown ${ }^{5}$ in Figure 7, is an expansion of the short version, because the basic structure - five components - is maintained, with the addition of elements belonging to each.

\footnotetext{
${ }^{5}$ High resolution figure: $\underline{\text { link }}$
} 


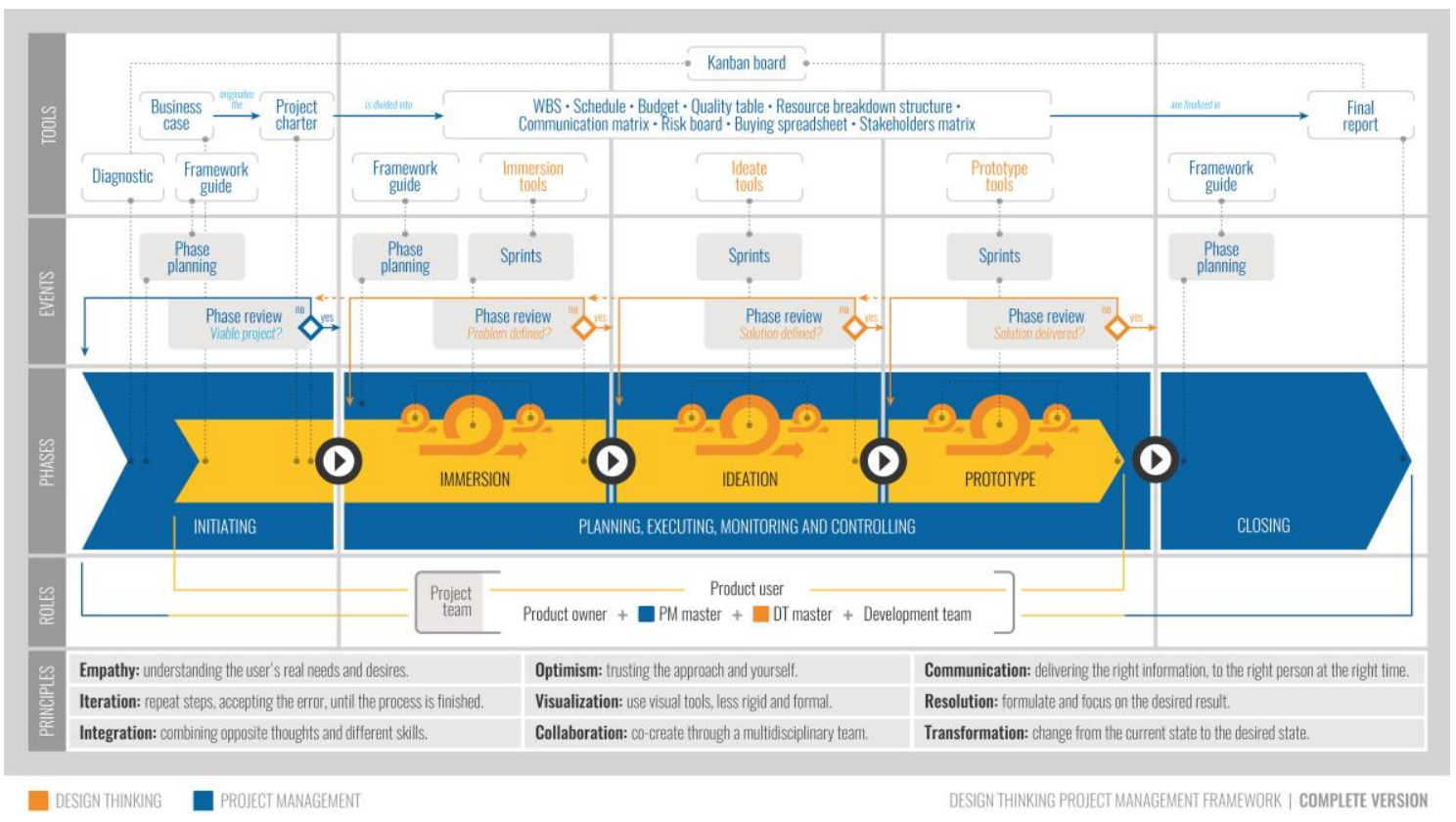

Figure 7 Design Thinking Project Management framework-DTPMf. Source: Authors (2021).

Given the considerable number of elements in the complete version of DTPMf, an attempt was made to build an easily understandable framework, using (i) only three colors to identify the elements: yellow for DT, blue for PM, gray for those belonging to DT and PM; (ii) simple and replicated shapes, such as arrows and rectangles with rounded corners, to provide quick recognition of each component; (iii) similar measures and positions for the components and their elements, with a visual balance guaranteed by symmetry.

Nine principles - empathy, iteration, integration, optimism, visualization, collaboration, communication, resolution and transformation - were listed and a brief explanation of each one was added to facilitate understanding. The choice was not to identify, textually or chromatically, the principles that originated from DT and those from PM. After all, the purpose of the framework is the integration of the two subjects, i.e., in practice, there is no difference if they originate in DT or PM, and they should be understood and practiced equally.

The five roles - product owner, PM master, DT master, development team and product user were positioned within the project team to indicate that they are all critical to the development of the project. However, two timestamps were added, signaling that the product user should participate during the DT phases, while the others, during the DT and PM phases. Similar to what was done with the principles, the origin of each role was not identified, only the role of the DT master and the PM master, because they are the only ones who must have specific knowledge.

The phases of the framework were represented by arrows, indicating an order of execution, and four vertical divisions were added to underline the beginning and end of each phase. The three phases of PM - initiating, planning, executing, monitoring and controlling, and closing were positioned below the three phases of the DT - immersion, ideation and prototype - to convey the idea of underpinning, to visually answer the research question: how can Design Thinking benefit from Project Management components? 
Although the duration of the phases, for both PM and DT, may vary, arrows with the same dimensions were used to maintain the framework's symmetry, avoid possible persuasion and emphasize the flexibility of adapting this component in different projects.

The DTPMf events were positioned according to each phase and reinforced by vertical dotted lines, indicating the moments at which they should happen. One questions was added to the phase review events and, at the end of each phase, the project team must decide whether to answer positively to the question and move forward or negatively and return to a previous phase of the project.

The tools of the framework were suggested when they were considered relevant for the project. However, the use of them depends on the needs of each project. The DT and PM tools were arranged in two ways: (i) fixed, where they belong to specific events - phase planning and Sprints - or originate other tools; (ii) flexible, i.e., they can be executed at different times - immersion tools, WBS, schedule, budget etc.

\section{Final considerations}

This research developed a framework, which allows managing DT projects in a structured and holistic way, minimizing the superficial perception often associated with DT. It is believed that the result can be used by practitioners and scholars from several fields of knowledge to further the debate on the positive contribution of PM to the creative and often chaotic approach to DT.

The integration between DT and PM was evident (i) in the principles, since four are equivalent and the remaining five are added to DT and PM to make them more complete; (ii) in the roles, since the project team was created by adding roles already existing in DT and PM, and by creating new roles - DT master and PM master -, inspired by both DT and PM; (iii) in the phases, since the PM phases created the necessary support for the DT phases, occurring in parallel, and the initial phase of the DT overlapped the simultaneous path between DT and PM; (iv) in the events, taking into account the use of events originating in PM for combined moments of DT and PM phase planning and review - and others - Sprints - for moments exclusively related to DT; (v) in the tools, because PM tools had the intent to complement the trajectory of DT and the initial tools of DT aimed to collect more information to assist in the execution of the PM tools.

However, the integration with PM cannot eliminate one of the fundamental aspects of DT: its flexibility. The formation of the DTPMf intended to maintain the fluidity of DT, adding managerial elements that increase the probability of project success, such as planning and control. The structure and components of the framework should not be understood as mandatory and static elements, but rather as suggestive and adaptable, because each project has unique needs and a unique approach to meeting them.

To deepen and discuss the theoretical and practical basis presented in this study, there should be future studies seeking to analyze other PM models, such as PRINCE2®, Lean and XP, to identify new components and/or confirm those previously detected, expanding the structure of the framework and its scope. Other management levels can be added to the study - organization, portfolio and/or program - to extend the DT beyond the project level. 


\section{References}

AJAM, Mounir A. Project Management beyond Waterfall and Agile. Boca Raton: CRC Press, 2018.

ALMENDRA, Rita; CHRISTIAANS, Henri. 'Design Thinking' The Emperor's New Suit. Design Principles and Practices, [s. 1.], v. 6, 2013.

AMORIM, Cleison Correia De. Um Modelo de Aplicação do Design Thinking para o Gerenciamento de Projetos de Inovação. [s. 1.], n. January, p. 0-22, 2017.

AUERNHAMMER, Jan; ROTH, Bernard. The origin and evolution of Stanford University's design thinking: From product design to design thinking in innovation management. Journal of Product Innovation Management, [s. 1.], n. February 2020, p. 1-22, 2021.

AXELOS. Managing Successful Projects with PRINCE2®. 6. ed. Norwich: The Stationery Office, 2017.

BEST, Kathryn. What can Design Bring to Strategy? Designing Thinking as a Tool for Innovation and Change. Rotterdam: Inholland University, 2011.

BROWN, Tim. Design thinking. Harvard Business Review, [s. 1.], v. 86, n. 6, p. 84-92, 2008.

BROWN, Tim. Change by design. New York: Harper Collins, 2009.

BROWN, Tim; WYATT, Jocelyn. Design Thinking for Social Innovation. Stanford Social Innovation Review, [s. 1.], v. Winter, p. 30-35, 2010.

CBD. O que você quer para a sua empresa? como inovar pelo design, 2016.

CIEB. Inovação aberta em educação: conceitos e modelos de negócios, 2016.

COOPER, Rachel; JUNGINGER, Sabine; LOCKWOOD, Thomas. Design Thinking and Design Management: A Research and Practice Perspective. Design Management Review, Oxford, v. 20, n. 2, p. 46-55, 2009.

COOPER, Robert G.; SOMMER, Anita F. The Agile-Stage-Gate Hybrid Model: A Promising New Approach and a New Research Opportunity. Journal of Product Innovation Management, [s. 1.], v. 33, n. 5, p. 513-526, 2016.

D.SCHOOL. Understand mixtape: Discovering insights via human engagementStanford, 2012.

DMI. Q\&A. DMI, [s. 1.], n. Summer, 2013.

DORST, Kees. Frame Creation and Design in the Expanded Field. She Ji: The Journal of Design, Economics, and Innovation, [s. 1.], v. 1, n. 1, p. 22-33, 2015.

GRUBER, Marc et al. Managing by Design. Academy of Management Journal, [s. 1.], v. 58, n. 1, p. 1-7, 2015. Disponível em: <http://journals.aom.org/doi/10.5465/amj.2015.4001〉

INNS, Tom. Theaters for Design Thinking. Design Management Review, Oxford, UK, v. 24 , n. 2 , p. $40-47,2013$.

IPMA. Individual Competence Baseline for Project, Programme \& Portfolio Management. 4. ed. Nijkerk: International Project Management Association, 2015.

JANGHORBAN, Roksana; ROUDSARI, Robab Latifnejad; TAGHIPOUR, Ali. Skype interviewing: The new generation of online synchronous interview in qualitative research. International Journal of Qualitative Studies on Health and Well-being, [s. 1.], v. 9, n. 1, 2014.

JOHANSSON-SKOLDBERG, Ulla; WOODILLA, Jill; ÇETINKAYA, Mehves. Design Thinking: Past, Present and Possible Futures. Creativity and Innovation Management, [s. 1.], v. 22, n. 2, p. 121-146, 2013. 
KELLEY, Tom; KELLEY, David. Creative Confidence: Unleashing the creative potential within us all. New York: Crown Buinsess, 2013.

KERZNER, Harold R. Project Management: A Systems Approach to Planning, Scheduling, and Controlling. 11. ed. New York: Wiley, 2015.

KIMBELL, Lucy. Rethinking Design Thinking: Part I. Design and Culture, [s. 1.], v. 3, n. 3, p. 285-306, 2011.

KUMAR, Vijay. 101 Design Methods: a structured approach for driving innovation in your organization. New Jersey: John Wiley \& Sons, Inc., 2013.

LAYTON, Mark C.; OSTERMILLER, Steven J. Agile Project Management For Dummies. 2. ed. Hoboken: John Wiley \& Sons, Inc., 2017.

LEAVY, Patrcia. Research Design: Quantitative, Qualitative, Mixed Methods, ArtsBased, and Community-Based Participatory Research Approaches. New York: The Guilford Press, 2017.

LEE, Hyun-Yeul Teresa. Storied Objects: Design Thinking with time. 2007. MASSACHUSETTS INSTITUTE OF TECHNOLOGY, [s. 1.], 2007.

LIEDTKA, Jeanne. Innovative ways companies are using design thinking. Strategy \& Leadership, [s. 1.], v. 42, n. 2, p. 40-45, 2014.

LIEDTKA, Jeanne. Exploring the Impact of Design Thinking in Action. Darden Working Paper Series, [s. 1.], v. 2017, n. 1, p. 1-48, 2018.

LIEDTKA, Jeanne; OGILVIE, Tim. Designing for growth: a design thinking tool kit for managers. New York: Columbia University Press, 2011.

LOCKWOOD, Thomas. Design thinking: integrating innovation, customer experience, and brand value. 3. ed. New York: Allworth Press, 2009.

MARTIN, Roger. Design thinking: achieving insights via the "knowledge funnel". Strategy \& Leadership, [s. 1.], v. 38, n. 2, p. 37-41, 2010.

MJV. O mapa da inovação no brasil 2017, 2017.

MJV. Design Thinking e Scrum no contexto da transformação digital. Rio de Janeiro: MJV Press, 2018. a.

MJV. Human Centered Design: como aplicar os conceitos no seu negócio. Rio de janeiro: MJV Technology \& Innovation, 2018. b.

MOSELEY, David et al. Frameworks for Thinking: A Handbook for Teaching and Learning. Cambridge: Cambridge University Press, 2005.

NITZSCHE, Rique. Afinal, o que é design thinking? São Paulo: Rosari, 2012.

NOTE, Margot. Project management for information professionals. Waltham: Elsevier, 2016.

O'TOOLE, Robert. Fit, Stick, Spread and Grow: Transdisciplinary studies of design thinking for the [re]making of Higher Education. 2015. University of Warwick, [s. 1.], 2015.

OLIVEIRA, Elisabete Regina Baptista De; VIANNA, Cláudia Pereira. Quando e como usar entrevistas por e-mail: reflexões com base em pesquisa sobre assexualidade. Educação em Revista, [s. 1.], v. 34, n. e192012, p. 1-22, 2018.

OMEJE, Ikenna Karl. Design Project Management: exploring the combination of Design Thinking process and the phase-oriented project management practice. 2015. KTH ROYAL INSTITUTE OF TECHNOLOGY, [s. 1.], 2015.

PLATTNER, Hasso; MEINEL, Christoph; LEIFER, Larry. Design Thinking Research. 
Berlin, Heidelberg: Springer Berlin Heidelberg, 2012.

PMI. Pulse of the profession: Aumento das taxas de sucesso. Transformando o alto custo. Newtown Square.

PRIES, Kim H.; QUIGLEY, Jon M. Scrum Project Management. Boca Raton: CRC Press, 2011.

REDLICH-AMIRAV, Dorit; HIGGINBOTTOM, Gene. New emerging technologies in qualitative research. The Qualitative Report, [s. 1.], v. 19, n. 26, p. 1-14, 2014.

ROGERS, Yvonne; SHARP, Helen; PREECE, Jenny. Design de interação: Além da interação homem-computador. 3. ed. Porto Alegre: Bookman, 2013.

SAUNDERS, Mark; LEWIS, Philip; THORNHILL, Adrian. Research Methods for Business Students. 7. ed. Harlow: Pearson Education Limited, 2016.

SEVERINO, Antônio Joaquim. Metodologia do trabalho científico. São Paulo: Cortez, 2013.

SOBEL, Leanne; GROEGER, Lars. The Future of Design Thinking in Australia: Barriers and Opportunities. Design Management Review, Oxford, UK, v. 24, n. 2, p. 26-31, 2013.

STERN, Terra Vanzant. Lean and Management Agile Project: How to Make Any Project Better, Faster, and More Cost Effective. Boca Raton: CRC Press, 2017.

STEWART, David W.; SHAMDASANI, Prem. Online Focus Groups. Journal of Advertising, [s. 1.], v. 46, n. 1, p. 48-60, 2016.

SUTHERLAND, Jeff. Scrum: a arte de fazer o dobro do trabalho na metade do tempo. São Paulo: LeYa, 2014.

TEIXEIRA, Carlos et al. Structures of Time in Design Thinking. In: Analysing Design Thinking: Studies of Cross-Cultural Co-Creation. 1. ed. London: CRC Press, 2017. p. 116.

TSCHIMMEL, Katja. Design Thinking as an effective Toolkit for Innovation. In: XXIII ISPIM CONFERENCE: ACTION FOR INNOVATION: INNOVATING FROM EXPERIENCE 2012, Barcelona. Anais... Barcelona: XXIII ISPIM Conference: Action for Innovation: Innovating from Experience., 2012.

TSCHIMMEL, Katja et al. D-Think Toolkit. Design Thinking Applied to Education and Training. Matosinhos: Erasmus+, 2017.

TURNER, J. Rodney. The Handbook of Project Based Management: Leading Strategic Change in Organizations. 3. ed. New York: The McGraw-Hill Companies, 2009.

VAN DER BIJL-BROUWER, Mieke; DORST, Kees. Advancing the strategic impact of human-centred design. Design Studies, [s. 1.], v. 53, p. 1-23, 2017.

VARGAS, Letícia Marques. Gerenciamento Ágil de Projetos em Desenvolvimento de Software: um estudo comparativo sobre a aplicabilidade do Scrum em conjunto com PMBOK e/ou PRINCE2. Revista de Gestão e Projetos, [s. 1.], v. 7, n. 3, p. 48-60, 2016.

VIANNA, Maurício et al. Design Thinking: Inovação em Negócios. Rio de Janeiro: MJV Press, 2012.

VON HIPPEL, Eric. An Emerging Hotbed of User-Centered Innovation. Harvard Business Review, [s. 1.], n. Fevereiro, 2007. 


\section{Sobre o autor}

\section{Daniel de Salles Canfield}

$\mathrm{PhD}$ in design from the Universidade Federal do Rio Grande do Sul, has a master's degree in marketing from Dublin Business School (Ireland), an MBA in strategic design from the Escola Superior de Propaganda e Marketing and a degree in Industrial Design/Visual Programming from the Universidade Federal de Santa Maria. He is currently an adjunct professor at the Universidade Federal de Goiás.

https://orcid.org/0000-0001-6255-5114

\section{Mauricio Moreira e Silva Bernardes}

Graduated in Civil Engineering from the Universidade Federal de Alagoas (1993), Master's (1996) and Ph.D. (2001) in Civil Engineering from the Universidade Federal do Rio Grande do Sul. Post-doctorate in design from the Institute of Design of the Illinois Institute of Technology/ USA. He is currently a full professor at the Universidade Federal do Rio Grande do Sul. http://orcid.org/0000-0002-3521-6974 